\title{
Mineral sequestration for CCS in Finland and abroad
}

\author{
Ron Zevenhoven ${ }^{1, *}$, Johan Fagerlund ${ }^{1}$ \\ ${ }^{1}$ Åbo Akademi University, Thermal and Flow Engineering Laboratory, Åbo/Turku, Finland \\ * Corresponding author. Tel: +358 2 2153323, Fax: +35822154792 E-mail: ron.zevenhoven@abo.fi
}

\begin{abstract}
The long-term storage of $\mathrm{CO}_{2}$ using mineral sequestration is becoming increasingly interesting in many regions, especially where $\mathrm{CO}_{2}$ underground sequestration is considered impossible or unfeasible. Despite the recognised and documented advantages of $\mathrm{CO}_{2}$ mineral sequestration, twenty years of R\&D work did not yet result in mature, economically viable technology that can be applied on a large scale. Lacking other CCS options while having access to large resources of suitable rock material, a route for carbonation of magnesium silicate mineral is currently being optimised in Finland. It involves the production of magnesium hydroxide, $\mathrm{Mg}(\mathrm{OH})_{2}$ from the mineral followed by carbonation of this in a pressurised fluidised bed reactor. Although the $\mathrm{Mg}(\mathrm{OH})_{2}$ production requires energy the consequent carbonation step is exothermic and the overall process could still be rendered energy neutral. Significant amounts of iron oxides are obtained as by-products. Carbonation levels of $\sim 50 \%$ of several $100 \mu \mathrm{m}$ diameter $\mathrm{Mg}(\mathrm{OH})_{2}$ particles were obtained within 10 minutes at pressures $>20$ bar and temperatures up to $500^{\circ} \mathrm{C}$. This paper reports on the latest developments of the work, addressing also process energy efficiency. Also, the large-scale application of this in Finland and at the locations of project partners abroad is briefly addressed.
\end{abstract}

Keywords: Carbon dioxide sequestration, Mineral carbonation

\section{Introduction}

The long-term storage of $\mathrm{CO}_{2}$ using mineral sequestration is becoming of increased interest in many regions, especially where $\mathrm{CO}_{2}$ underground sequestration is not possible or considered unfeasible. At many locations worldwide very large deposits of suitable mineral, usually magnesium silicates (serpentine, olivine) but sometime also calcium silicates (wollastonite) are available. Examples for this are Finland, East-coast Australia, Portugal and regions at the west coast of the USA and Canada. Despite the recognised and documented advantages of $\mathrm{CO}_{2}$ mineral sequestration (very large capacity, no pos t-storage monitoring needed, exothermic overall process chemistry) the development work is still in the laboratory demonstration scale: twenty years of $R \& D$ work did not yet result in mature technology that can be applied on a large scale in an economically viable way $[1,2,3]$. Motivated by the slow deployment of large scale underground storage of $\mathrm{CO}_{2}$ or simply the availability of large amounts of suitable mineral, progress on mineral sequestration is being steadily made and reported from an increasing number of research teams and projects worldwide. Also, increasingly realistic understanding of usable storage capacity for underground sequestration is changing the relative positioning of different CCS methods [4]. As a result, $\mathrm{CO}_{2}$ mineral sequestration shows a cl ear trend towards scale-up and commercialisation, as is further illustrated by a significant number of patents awarded quite recently $[5,6]$. In addition, the issue of what to do with the solid product material has resulted in developments in $\mathrm{CO}_{2}$ mineral sequestration towards both low value (land reclamation) and high value (pharmaceutics) applications.

Development work in Finland, where the exothermic carbonation chemistry is the reason for focussing on hi gh temperature, gas/solid carbonation at elevated pressures involves cooperation with a growing list of international partners, such as in the Baltic states Estonia and Lithuania but also in the Netherlands, Portugal, UK and more recently also Canada and Singapore. The route for carbonation of magnesium silicate mineral as currently being optimised at Åbo Akademi University ( $\AA$ A) in Finland involves the production of magnesium 
hydroxide, $\mathrm{Mg}(\mathrm{OH})_{2}$ from the mineral followed by carbonation of this in a pressurised fluidised bed (PFB) reactor. Although the $\mathrm{Mg}(\mathrm{OH})_{2}$ production step requires energy the consequent carbonation step is exothermic and the overall process could still be rendered energy neutral (or even negative). This energy recovery distinguishes the method from other routes for $\mathrm{CO}_{2}$ mineralisation. In addition, significant amounts of iron oxides are obtained as by-products [7]. Carbonation levels of $\sim 50 \%$ of several $100 \mu \mathrm{m}$ diameter $\mathrm{Mg}(\mathrm{OH})_{2}$ particles where obtained within 10 minutes at pressures $>20$ bar and temperatures up to $500{ }^{\circ} \mathrm{C}$ [8-11]. The production of $\mathrm{Mg}(\mathrm{OH})_{2}$ currently requires more heat than is generated by its carbonation, but nonetheless this route shows similar or better energy economics $(0.9-1.2$ vs. $1.0-2.3$ $\mathrm{kWh} / \mathrm{kg} \mathrm{CO}$ fixed) than the more straightforward route that is widely considered as "state of the art", i.e., direct mineral carbonation of superheated aqueous suspensions under high $\mathrm{CO}_{2}$ pressure $\left[12,1\right.$ (p. 326)]. The route via $\mathrm{Mg}(\mathrm{OH})_{2}$ also shows (much) faster carbonation kinetics than the conventional process, especially for larger particles - see below for more detail and results. One important benefit of the stepwise approach is that oxides of iron and calcium are obtained as separate by-products, such that magnesite $\left(\mathrm{MgCO}_{3}\right)$ is the unique carbonation product. The main mineral contaminant (iron oxide) thus extracted is sufficiently abundant to be of interest to the iron- and steelmaking industry [13].

This paper reports on the latest results of the development work where the carbonation of several rock types are compared, addressing the production of $\mathrm{Mg}(\mathrm{OH})_{2}$ and the rate and final level of $\mathrm{Mg}(\mathrm{OH})_{2}$ carbonation, and process energy efficiency. Also, the application of this for large-scale $\mathrm{CO}_{2}$ mineral sequestration in Finland and at the locations of our project partners abroad will be addressed. This includes the use of the (by-) products of the process which can be used for land reclamation (as is an objective in Singapore), heat storage, or iron- and steelmaking. Finding such uses or markets for the solid products and by-products is essential.

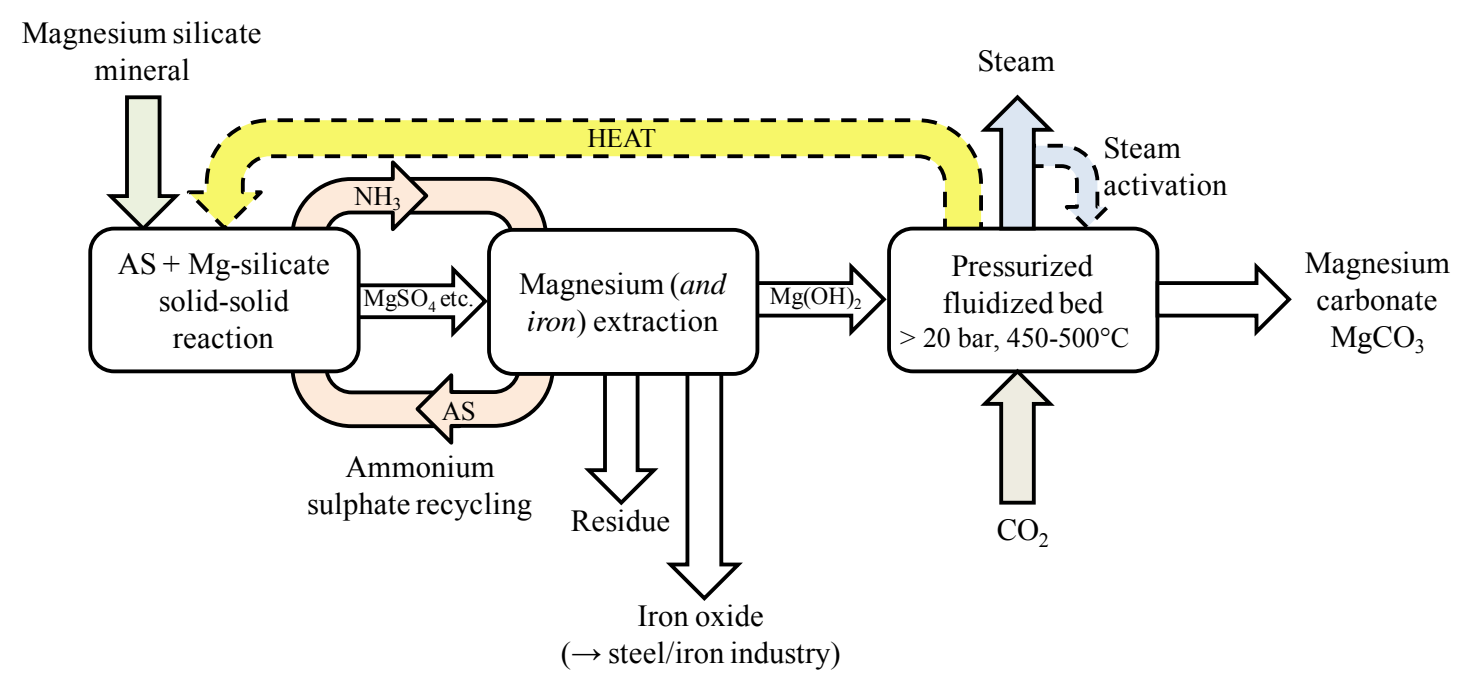

Fig. 1. A schematic illustration of the mineral carbonation process under development at $\AA A$

\section{Process description: serpentinite carbonation via $\mathrm{MgSO}_{4}$ and $\mathrm{Mg}(\mathrm{OH})_{2}$}

The staged process under development at $\AA$ A is schematically given in Fig. 1. As raw material, serpentinite rock rich in serpentine $\left(\mathrm{Mg}_{3} \mathrm{Si}_{2} \mathrm{O}_{5}(\mathrm{OH})_{4}\right)$ is considered (being abundant in Finland), although most carbonation tests have been made using a commercial $\mathrm{Mg}(\mathrm{OH})_{2}$ sample. Besides this, tests were made with magnesium silicate-based rock material from Lithuania, Portugal, Australia and other locations [14,15]. Table 1 lists selected composition data for some of the materials studied. 
Table 1. Composition of some of the magnesium silicate rock samples being studied

\begin{tabular}{ccccccc}
\hline Rock & $\begin{array}{c}\mathrm{MgO} \\
(\% \mathrm{wt})\end{array}$ & $\begin{array}{c}\mathrm{CaO} \\
(\% \mathrm{wt})\end{array}$ & $\begin{array}{c}\mathrm{Fe}_{2} \mathrm{O}_{3} * \\
(\% \mathrm{wt})\end{array}$ & $\begin{array}{c}\mathrm{SiO}_{2} \\
(\% \mathrm{wt})\end{array}$ & $\begin{array}{c}\mathrm{Al}_{2} \mathrm{O}_{3} \\
(\% \mathrm{wt})\end{array}$ & $\begin{array}{c}\text { Others } \\
(\% \mathrm{wt})\end{array}$ \\
\hline Hitura, FI & 38.1 & 0.5 & 14.8 & 47.6 & 10.0 & 6.2 \\
Vammala, FI & 14.5 & 5.6 & 12.5 & 49.5 & 8.8 & 9.1 \\
Varena, LT & 31.4 & 1.2 & 17.6 & 34.0 & 0.5 & 15.3 \\
Braganca, PT & 35.8 & $<0.1$ & 8.2 & 41.9 & 1.2 & 12.9 \\
Great Serpentine Belt, AU & 49.0 & $<0.1$ & 6.9 & 41.9 & 1.8 & 0.4 \\
\hline
\end{tabular}

* Calculated, presumably a mixture of $\mathrm{FeO}$ and $\mathrm{Fe}_{2} \mathrm{O}_{3}$, i.e. $\mathrm{Fe}_{3} \mathrm{O}_{4}$.

\section{1. $\mathrm{Mg}(\mathrm{OH})_{2}$ production}

In the first process step, (preheated) serpentinite rock is thermally treated with ammonium sulphate (AS) at $400-500{ }^{\circ} \mathrm{C}$ and atmospheric pressure for $10-60$ minutes. A significant amount of the magnesium, $\mathrm{Mg}$, in the rock is thus converted to sulphate, $\mathrm{MgSO}_{4}$, which is highly soluble in water. Unfortunately, $\mathrm{MgSO}_{4}$ cannot be directly converted with $\mathrm{CO}_{2}$ to $\mathrm{MgCO}_{3}$, but in an aqueous solution it can be converted to $\mathrm{Mg}(\mathrm{OH})_{2}$. After cooling, the solid from the reaction with AS is slurried in water, leaving behind unreacted mineral and insoluble reaction products, e.g., silica. The $\mathrm{pH}$ of the filtrate solution is raised to $8-9$, precipitating iron and calcium (from the mineral, see Table 1) as $\mathrm{FeOOH}$ and $\mathrm{Ca}(\mathrm{OH})_{2}$, respectively, while increasing the $\mathrm{pH}$ further to $10-11$ precipitates $\mathrm{Mg}(\mathrm{OH})_{2}$. For the Finnish Hitura mineral, the preferable conditions for extraction of $\mathrm{Mg}$ (and $\mathrm{Fe}$ ) to $\mathrm{MgSO}_{4}$ (and $\mathrm{FeSO}_{4}$ ) are temperatures $400-440{ }^{\circ} \mathrm{C}$, for $30-60$ minutes at $\mathrm{S} / \mathrm{AS}=0.5-0.7 \mathrm{~kg} / \mathrm{kg}$, with $60-66 \%$ extraction of $\mathrm{Mg}$. Lower temperatures and longer reaction times give a higher (relative) extraction of iron. Ammonia vapour, $\mathrm{NH}_{3}$, released during the thermal step is collected and used to give the necessary $\mathrm{pH}$ increases for precipitation. It is thereafter recovered for regeneration of the AS salt downstream, using heat from another process step. Nonetheless, the recovery of solid ammonium sulphate from the aqueous form incurs a not insubstantial energy penalty.

\section{2. $\mathrm{Mg}(\mathrm{OH})_{2}$ carbonation}

The $\mathrm{Mg}(\mathrm{OH})_{2}$ produced as described above is converted into $\mathrm{MgCO}_{3}$ in a pressurised fluidised bed (PFB) reactor at pressures $>20$ bar and temperatures $450-600{ }^{\circ} \mathrm{C}$. Results on conversion levels obtained under varying conditions (temperature, pressure, water content of the gas, time, fluidisation velocity) are reported elsewhere [9-11] for both the synthetic, commercial $\mathrm{Mg}(\mathrm{OH})_{2}$ material and $\mathrm{Mg}(\mathrm{OH})_{2}$ produced from Finnish or Lithuanian serpentinites. A few tests were made under supercritical $\mathrm{CO}_{2}$ conditions (pressure $>74 \mathrm{bar}$ ) which showed significantly lower conversion levels and rates, suggesting that little benefit should be expected from operating at such pressure levels. It was found that the $\operatorname{Mg}(\mathrm{OH})_{2}$ materials produced from the serpentinites are much more reactive (as a result of a $\sim 10 \times$ larger specific surface of $\sim 45 \mathrm{~m}^{2} / \mathrm{g}$ vs. $\sim 5 \mathrm{~m}^{2} / \mathrm{g}$ ), giving conversion levels of $50 \%$ within 15 minutes for $\sim 300 \mu \mathrm{m}$ particles. The product gas from the carbonator is a hot, pressurised mixture of $\mathrm{CO}_{2}$ and $\mathrm{H}_{2} \mathrm{O}$, the solids obtained will be partly recycled for further carbonation conversion. Unfortunately, although the carbonation reaction is rapid it levels off at a carbonation level of $50-55 \%$ for the synthetic, commercial $\mathrm{Mg}(\mathrm{OH})_{2}$ which may be the result of calcination of $\mathrm{Mg}(\mathrm{OH})_{2}$ to $\mathrm{MgO}$. However, it is noted that in order for $\mathrm{Mg}(\mathrm{OH})_{2}$ to carbonate, dehydroxylation (i.e. calcination) has to occur. Apparently, carbonation takes place at a slower rate than dehydroxylation, resulting in a partially calcined and carbonated product. The amount of $\mathrm{Mg}(\mathrm{OH})_{2}, \mathrm{MgO}$ and $\mathrm{MgCO}_{3}$ in samples after test is plotted in Fig. 2 as a function of temperature for $\sim$ twenty experiments $\left(\mathrm{CO}_{2}\right.$ pressure range $20-58$ bar) with varying experiment time, fluidisation velocity, particle size, etc. 


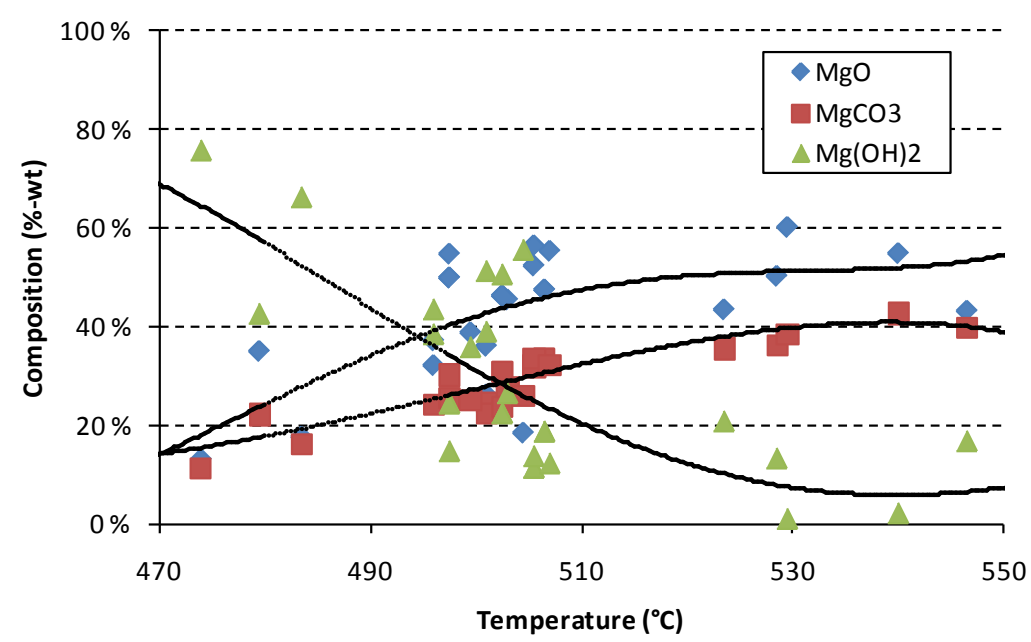

Fig. 2. Composition of Mg-species as a function of temperature for various experimental conditions using a PFB reactor [11].

\subsection{Process (energy) efficiency}

One of the features of $\mathrm{CO}_{2}$ mineralisation using magnesium silicates is that the overall chemical reaction is exothermic. However, the direct carbonation of magnesium silicates is too slow, too energy demanding, or otherwise economically unviable, although work on improving the rate of processes based on pressurised aqueous solutions is still ongoing at several locations [3,6]. For the process route presented above an analysis was made of the heat requirement of the thermal treatment of Finnish Hitura (nickel mine tailing) serpentinite (see Table 1) with ammonium sulphate and the heat generated by carbonation of the resulting $\mathrm{Mg}(\mathrm{OH})_{2}$. This showed that producing $\mathrm{Mg}(\mathrm{OH})_{2}$, at $400-500{ }^{\circ} \mathrm{C}$ will require $4 \times$ more heat than what is obtained, at $450-550{ }^{\circ} \mathrm{C}$, from carbonating it. Although $\sim 1.2 \mathrm{MJ} / \mathrm{kg} \mathrm{CO}_{2}$ can be recovered as reaction heat the overall heat input requirements add up to $4-5 \mathrm{MJ} / \mathrm{kg} \mathrm{CO}_{2}$, consuming $3-4$ ton rock per ton $\mathrm{CO}_{2}$ [16]. An improved design using pinch analysis to optimise the heat exchanger network of the process, followed by process simulation with Aspen Plus ${ }^{\circledR}$ and exergy analysis (of the process heat input and outputs) reduces this to $\sim 3$ $\mathrm{MJ} / \mathrm{kg} \mathrm{CO} \mathrm{CO}_{2}$ heat input requirements while consuming $\sim 3.1$ ton rock per ton $\mathrm{CO}_{2}$. The regeneration of ammonium sulphate (AS), which is obtained as aqueous solution after $\mathrm{Mg}(\mathrm{OH})_{2}$ precipitation (while powdered, dry AS is used in the thermal treatment of serpentinite) puts a high energy penalty on the process [16].

It has been reported [17] that AS crystallisation from an aqueous solution can be accomplished at $\sim 90{ }^{\circ} \mathrm{C}$ against a moderate heat input of $\sim 120 \mathrm{~kW} / \mathrm{m}^{3}$ (residence time 95 minutes in a $0.97 \mathrm{~m}^{3}$ DTB crystalliser). Nonetheless, a less energy consuming alternative for the AS recovery must be found and the solid/solid extraction must be improved, not only for energetic reasons, but also to recover more by-products thereby reducing the amount of solid residue. The rather high solubility of magnesium sulphate and ammonium sulphate in water should allow the use of minimal amounts of water in the precipitation steps towards $\mathrm{Mg}(\mathrm{OH})_{2}$. Further improvement is obtained by optimising the different temperatures in the three aqueous precipitation steps. A variety of process refinements that lead to better energy efficiency, extraction from serpentinite, and AS recovery, was recently reported by Romão et al. [14] A recent study by Björklöf [18] applies mechanical vapour recompression (MVR) for the recovery of AS salt, making use of pinch analysis combined with chemical exergy analysis (in a spreadsheet calculation). The outcome of the study gives an energy penalty of $5.54 \mathrm{MJ} / \mathrm{kg} \mathrm{CO}$ fixed, expressed as exergy (using conservative data for the magnesium 
sulphate solubility in water). Fig. 3 gives a so-called Grassmann diagram that clearly points out the exergy destruction in the various stages. Similar to Romão et al. [14,16] the energy penalty of the process (as exergy losses) was identified to arise primarily from 1) the AS recovery from dilute aqueous solutions, 2) the magnesium extraction using AS, and 3) the cooling of hot extraction products to aqueous solution temperature.

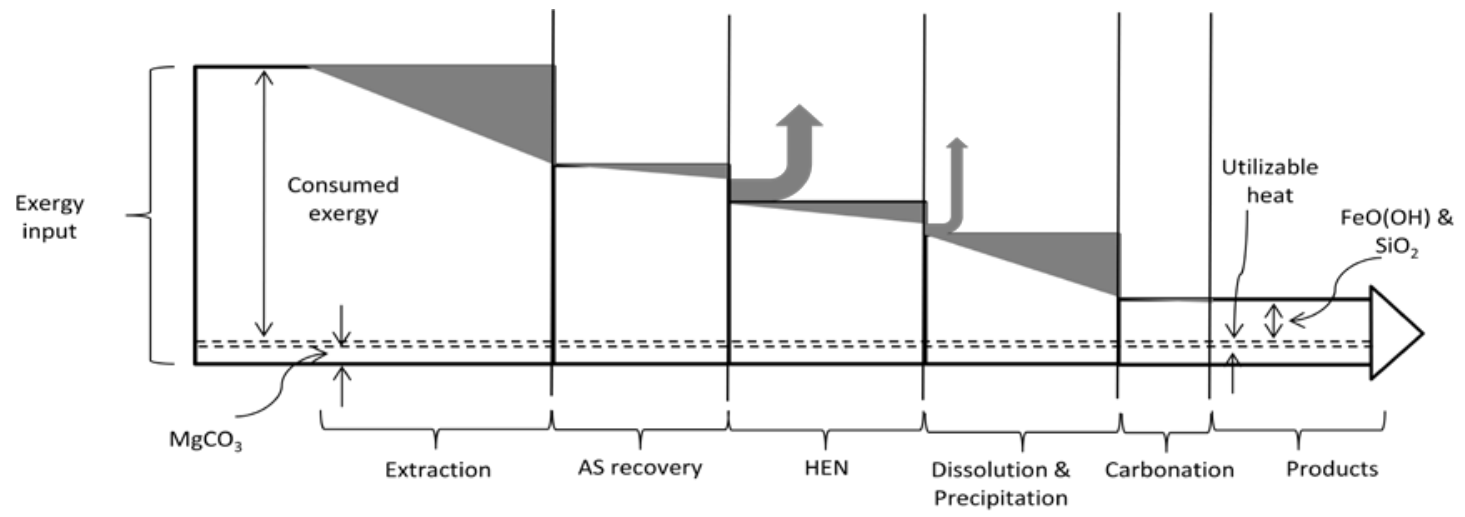

Fig. 3. A Grassmann diagram of the staged $\AA A$ process. The gray triangles represent exergy destruction in the various process steps and the arrows represent exergy losses. At the far right, the products consist of the chemical exergies of the products and the recoverable heat from the carbonation step. [18]

\subsection{Magnesium extraction and carbonation efficiency, ammonium sulphate recovery}

Besides carbonation efficiencies for $\mathrm{Mg}(\mathrm{OH})_{2}$ in the PFB levelling off at 50-55\% (for a synthetic, commercial sample) also the extraction of magnesium from serpentinite needs improvement, with extraction efficiencies obtained so far seldom exceeding $60 \%$ of the $\mathrm{Mg}$ content of the rock. For this, development work commences at $\AA$ A, aiming at using a rotary kiln for the magnesium extraction, instead of using a fixed bed ("heap") for the conversion because this requires higher temperatures than necessary to compensate for heat and mass transfer limitations. The excess temperature leads to irreversible loss of the AS salt as $\mathrm{SO}_{2}$ and $\mathrm{N}_{2} \mathrm{O}$. Detailed chemical reaction and solid product analysis suggest that temperatures should not exceed $400{ }^{\circ} \mathrm{C}$. The possibility of losses of AS, e.g., occluded within the solid residue of unreacted serpentinite, silica etc., or in the $\mathrm{Mg}(\mathrm{OH})_{2}$ fed to the carbonator (probably as $\mathrm{NH}_{4}{ }^{+} \& \mathrm{SO}_{4}{ }^{2-}$ ions) was addressed by Björklöf [18]. Analysis showed that the solid residue contained $<0.1 \%$-wt nitrogen and $<0.9 \%$-wt sulphur which corresponds to $~$ $0.15 \%$ and $\sim 1.5 \%$, respectively, of the incoming AS. For the $\operatorname{Mg}(\mathrm{OH})_{2}$ the nitrogen - and sulphur contents were $0.1 \%$-wt and $0.8 \%$-wt, respectively.

\section{Implementation of the results in Finland and abroad}

Finland, like many countries in the EU, has commitments with respect to greenhouse gas emissions under the Kyoto Protocol and a continuation of the use of fossil fuels may be difficult without also implementing a CCS method. In Finland, the following schemes can be considered - see also Fig. 4 for industry sector integration:

- $\mathrm{CO}_{2}$ from large-scale producers in Central / Northern Finland can be fixed using the vast resources of serpentinite-containing rock (estimated CCS capacity $2.5-3.5 \mathrm{Gt} \mathrm{CO}_{2}$ [19]). One example is Ruukki's iron- and steelmaking plant at Raahe, which is $\sim 110 \mathrm{~km}$ from the nickel mine at Hitura where large amounts of mine tailings are deposited. At the same time, large amounts of iron oxide by-products will be obtained from the rock, ready for use at the iron- and steelmaking plant. And, the slag by-products, most importantly steel 
converter slag, may be carbonated to yield valuable calcium carbonates of PCC (precipitated calcium carbonate) quality [20].

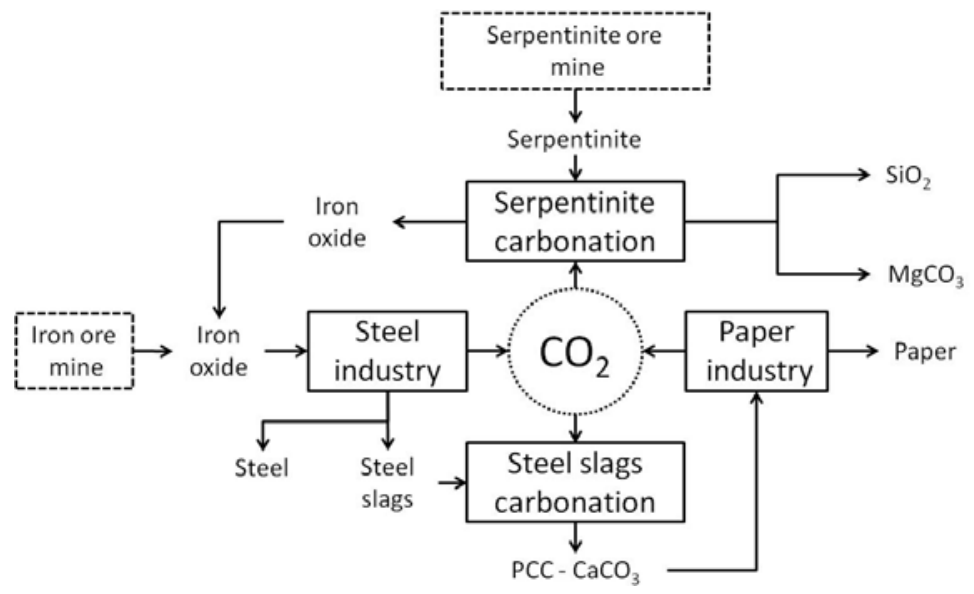

Fig. 4. Integrated processing for magnesium silicate carbonation, iron- and steelmaking and steel slag carbonation [13]

- With most $\mathrm{CO}_{2}$ produced in Southern Finland, lower-grade minerals than found in Central/Northern Finland must be made use of. At several locations in South / South-west Finland rock with an $\mathrm{MgO}$ content of 10-15\%-wt were found, offering potential for source-sink combinations such as

* Vammala serpentinite for use at the coal-fired plant at Meri-Pori (distance $\sim 90 \mathrm{~km}$ )

* Suomusjärvi serpentinite for use at a lime kiln in Parainen (distance $\sim 90 \mathrm{~km}$ ) or at a power plant in Naantali (distance $\sim 95 \mathrm{~km}$ )

Also abroad the technology can be made use of, for example our cooperation with:

- Lithuania, where significant and suitable (although maybe located somewhat deep) serpentinite were found in the Varena region in the South-east of the country [15]

- In Portugal, suitable rock was located at several locations within the country [14], offering good opportunities for $\mathrm{CO}_{2}$ mineralisation while also the option of (on-shore) underground sequestration is being investigated [21]

- Singapore, where CCS is combined with land reclamation during the next decade, using rock material that is imported from the region, for example from Australia [22]

In most of the cases, except the last mentioned obviously, $\mathrm{CO}_{2}$ would be transported to the mineral site. On the other hand, like fossil fuels, metal ores or other raw material also rock transport can be feasible, with the advantage that the carbonation process can operate directly on the $\mathrm{CO}_{2}$-containing gases. This removes the $\mathrm{CO}_{2}$ capture step from the CCS chain.

\section{Conclusions}

The performance and efficiency (with respect to energy and chemicals recovery) of a staged process for serpentinite carbonation as under development at $\AA$ A was described and assessed. It involves the production of magnesium hydroxide, $\mathrm{Mg}(\mathrm{OH})_{2}$ from the mineral using ammonium sulphate, AS (which is later recovered) followed by carbonation of this in a pressurised fluidised bed (PFB) reactor. The process can be considered to be a variety of a process route patented by Pundsack in 1967 [23], which is based on extraction of magnesium from serpentine using an aqueous solution of ammonium bisulphate (ABS). The $\AA$ A route for serpentinite carbonation, instead, uses AS in a high temperature step for magnesium 
extraction that proceeds much faster than that with ABS in an aqueous solution $(<<1 \mathrm{~h}$ vs. $>>$ $1 \mathrm{~h}$ ) whilst also the reaction heat release from the carbonation is taken advantage of in the gas/solid reactor. However, recovery of solid ammonium sulphate from the aqueous form incurs a not insubstantial energy penalty. Thus, there seems to be a need to develop an alternative route to $\mathrm{Mg}(\mathrm{OH})_{2}$ that bypasses the aqueous stage, and/or a route in which $\mathrm{MgSO}_{4}$ is carbonated directly, e.g., using ammonium (bi)carbonate produced from $\mathrm{CO}_{2}$ absorption in (aqueous) ammonia in an upstream scrubbing stage. Ammonium sulphate is a cheap and abundant reagent for extracting magnesium from serpentinite, but its performance must be evaluated under milder conditions as predicted by thermodynamics. The other technical issue linked with its use is the containment of $\mathrm{NH}_{3}$ in the system.

Ammonium salts, i.e., (bi-)carbonate and (bi-) sulphate, could play an important role for extracting magnesium from rock material and as reactants produced from scrubbing $\mathrm{CO}_{2}$ from process gases with chilled aqueous ammonia solutions - see for example [24]. An important benefit of the $\mathrm{CO}_{2}$ mineral sequestration routes that look most promising for scaleup and large-scale application is that the expensive and potentially problematic $\mathrm{CO}_{2}$ capture stage can be removed from the CCS chain. This is one of the drivers of current interest for $\mathrm{CO}_{2}$ mineral sequestration. It is also considered for the $\AA \mathrm{A}$ process route, although the gas/solid carbonation will require $\mathrm{CO}_{2}$ partial pressures $>20 \mathrm{ba}$. On the other hand, scrubbing $\mathrm{CO}_{2}$ from a power plant flue gas will introduce water and other species (and potential contaminants) into the process loop, eventually contaminating the sorbent.

\section{Acknowledgements}

This work was supported by the Academy of Finland program "Sustainable Energy" (2008 2011), with further support from KH Renlund Foundation (2007 - 2009). Thomas Björklöf, Experience Nduagu and Joel Songok of ÅA, Inês Romão of the University of Coimbra, Portugal and Dr. James Highfield of ICES/A*Star, Singapore are acknowledged for valuable comments and contributions.

\section{References}

[1] IPCC. Special Report on Carbon Dioxide Capture and Storage. Metz, B., Davidson, O., de Coninck, H.C., Loos, M., Meyer, L.A. (Eds.) Cambridge University Press, 2005.

[2] Lackner, K S. A guide to $\mathrm{CO}_{2}$ sequestration. Science 300, 2003, pp. 677-1678.

[3] Zevenhoven, R., Fagerlund, J. Mineralisation of $\mathrm{CO}_{2}$ Chapter 16 in: Developments and innovation in CCS technology M. Maroto-Valer (Ed.), Woodhead Publishing Ltd., Cambridge (UK), 2010, pp 433-462

[4] IEA. Carbon capture and storage - Progress and next steps. IEA/CSLF Report to the Muskoka 2010 G8 Summit. IEA, Paris, 2010, 39 pp.

[5] Delgado Torróntegui, M. Assessing the mineral carbonation science and technology M.Sc. Thesis ETH Zürich, Switzerland, 2010

[6] Zevenhoven, R., Fagerlund, J., Songok, J.K. $\mathrm{CO}_{2}$ mineral sequestration - developments towards large-scale application. Greenhouse Gases: Science and Technology, 2011, accepted / in press doi: 10.1002/ghg3.007

[7] Nduagu, E. Mineral carbonation: preparation of magnesium hydroxide $\left[\mathrm{Mg}(\mathrm{OH})_{2}\right]$ from serpentinite rock, M.Sc. Thesis, Åbo Akademi University, Finland, 2008

[8] Fagerlund, J. Teir, S. Nduagu, E., Zevenhoven, R. Carbonation of magnesium silicate mineral using a pressurized gas/solid process. Energia Procedia 1, 2009, pp. 4907-4914. 
[9] Fagerlund, J., Nduagu, E., Romão, I., Zevenhoven, R. A stepwise process for carbon dioxide sequestration using magnesium silicates. Front. Chem. Eng. China 4(2), 2010, pp. 133-141.

[10]Fagerlund, J., Nduagu, E. Zevenhoven, R. Recent developments on the carbonation of serpentinite- derived $\mathrm{Mg}(\mathrm{OH})_{2}$ using a pressurised fluidised bed. Presented at GHGT-10, Amsterdam (the Netherlands) September 19-23, 2010. (Energia Procedia 2011)

[11]Fagerlund, J., Nduagu, E., Romão, I. \& Zevenhoven, R. $\mathrm{CO}_{2}$ fixation using magnesium silicate minerals. Part 1: Process description and performance. Energy - the Int. J. (special edition ECOS2010), submitted (October 2010)

[12] Gerdemann, S.J., O’Connor, W.K., Dahlin, D.C., Penner, L.R., Rush, H. Ex Situ Aqueous Mineral Carbonation Environ. Sci. Technol. 41, 2007, pp. 2587-2593

[13]Zevenhoven, R., Fagerlund, J., Nduagu, E., Romão. I. Mineralisation of $\mathrm{CO}_{2}$ and recovery of iron using serpentinite rock. Proceedings of R'09, Davos (Switzerland), Sept. 14-16, 2009 (paper 149)

[14]Romão, I., Gando Ferreira, L. M., Fagerlund, J., Zevenhoven, R. $\mathrm{CO}_{2}$ sequestration with Portuguese serpentinite. in: Proceedings of ACEME10, Turku (Finland) Nov. 29 - Dec.1, 2010, p. $77-87$

[15] Stasiulaitiene I., Fagerlund J., Nduagu E., Denafas G., Zevenhoven R. Carbonation of serpentinite rock from Lithuania and Finland. Presented at GHGT-10, Amsterdam (the Netherlands) September 19-23, 2010. (Energia Procedia 2011)

[16]Romão, I., Nduagu, E., Fagerlund, J., Gando-Ferreira, L. M. \& Zevenhoven, R. $\mathrm{CO}_{2}$ Fixation Using Magnesium Silicate Minerals. Part 2: Energy Efficiency and Integration with iron-and steelmaking. Energy - the Int. J. (special edition ECOS2010), submitted (October 2010)

[17] O'Meadhra, R., and van Rosmalen, G.M. Scale-up of ammonium sulphate crystallization in a DTB Crystallizer. Chem. Eng. Sci. 51(16), 1996, pp. 3943-3950

[18]Björklöf, T. An energy efficiency study of carbon dioxide mineralization. M.Sc. Thesis, Åbo Akademi University, Finland, 2010

[19]Teir, S. Fixation of carbon dioxide by producing carbonations from minerals and steelmaking slags. PhD (Eng) thesis, Helsinki Univ, of Technol., Espoo Finland, 2008

[20] IEA, Carbon capture and storage: a key carbon abatement option. IEA, Paris, France, 2008. pp. 189-190

[21]Eloneva, S. Reduction of $\mathrm{CO}_{2}$ emissions by mineral carbonation: steelmaking slags as raw material with a pure calcium carbonate end product. $\mathrm{PhD}$ (Eng) thesis, Aalto Univ. School of Sci and Technol., Espoo Finland, 2010

[22]Khoo, H.H., Sharatt, P.N., Bu, J., Borgna, A., Yeo, T.Y., Khor, T.Y., Björklöf, T.G., Zevenhoven, R. Carbon capture and mineralization in Singapore: preliminary environmental impacts and costs via LCA. Sci. Total Environ., submitted (July 2010)

[23]Pundsack, F.L., Recovery of silica, iron oxide and magnesium carbonate from the treatment of serpentine with ammonium bisulphate. U.S. Patent 3,338,667, 1967

[24]Hunwick, R.J., System, apparatus and method for carbon dioxide. World patent WO2008101293(A1), Australian patent AU2008000232, 2008 